\title{
СИНОПТИЧНА ХАРАКТЕРИСТИКА ФАКТОРІВ РИЗИКУ ВИНИКНЕННЯ РАКУ ТІЛА МАТКИ ТА РАКУ ЯЄЧНИКІВ
}

\author{
Національна медична академія післядипломної освіти імені П.Л. Шупика, м. Київ, Україна
}

\begin{abstract}
Мета: встановити провідні фрактори у розвитку раку тіла матки і раку яєчників та на їх основі визначити основні групи ризику розвитку онкогінекологічної патології.

Матеріали і методи. На основі проведеного епідеміологічного дослідження, яке включало 278 жінок Тернопільської області за період 2014-2016 рр., серед яких у 155 діагностовано рак тіла матки та у 123 - рак яєчників, визначено фактори ризику розвитку онкогінекологічної патології.

Результати. Встановлено фрактори ризику, серед яких найбільш інформативними є вік, відсутність шлюбу, пізня та рання менопаузи, нерегулярне або перерване статеве життя, штучні аборти, ендокринно-обмінні захворювання.

Висновки. Виділено 3 групи ризику розвитку у жінок онкогінекологічної патології: перша група - хворі на рак, передракові та фронові захворювання тіла матки і яєчників; друга група - практично здорові жінки з чотирма і більше фракторами ризику; третя група - практично здорові жінки з 1-3 фракторами ризику, які мають незначну питома частку у виникненні онкогінекологічної патології.
\end{abstract}

КЛЮчОВІ СЛОВА: рак тіла матки; рак яєчників; фактори ризику.

Злоякісні пухлини жіночих репродуктивних органів у багатьох країнах Європи, США, у тому числі й в Україні, займають одне з провідних місць в структурі загальної онкологічної захворюваності та смертності жіночого населення. Це зумовлено стрімким зростанням раку шийки матки, тіла матки та яєчників $[1,2]$. Для багатьох регіонів однією 3 найважливіших проблем $є$ необхідність усунення впливу фракторів ризику онкологічної захворюваності та зниження рівня захворюваності, смертності та інвалідності $[3,4]$. У структурі онкологічної захворюваності жінок злоякісні пухлини шийки матки складають близько 20 \% і серед онкопатології статевих органів стабільно займають друге місце після раку ендометрія [5]. Зростання захворюваності на рак тіла матки та яєчників спостерігають в більшості розвинених країн. Аналогічну тенденцію простежують і в Україні. Висока питома частка раку жіночих статевих органів у структурі загальної онкологічної захворюваності та смертності жінок, зростання захворюваності на рак тіла матки та яєчників ставлять цю патологію в ряд найбільш актуальних проблем медико-соціального значення. Однак, незважаючи на збільшення контингенту населення, яке піддається профрілактичним оглядам із застосуванням цитологічного скринінгу, питома частка активного виявлення хворих на рак залишається дуже низькою $[6,7]$. Це визначає необхідність підвищення ефективності профрілактичних обстежень серед осіб із високим ризиком захворювання на рак шийки матки, тіла матки і яєчників. Результати наукових досліджень

(с) М.П. Романів, В.М. Михальчук, 2017 свідчать, що в останні роки спостерігається зменшення впливу на репродуктивні органи жінки екзогенних фракторів ризику і значне збільшення впливу деяких ендогенних факторів. Це зумовлено зниженням рівня народжуваності, збільшенням позашлюбних зв'язків, наявністю однодітних сімей, застосуванням протизаплідних засобів, нераціональним харчуванням, збільшенням питомої частки жінок із надмірною масою тіла і порушенням обміну речовин.

Подальший пошук шляхів профілактики, прагнення знизити рівень захворюваності на злоякісні пухлини і підвищити ефективність лікування привели до необхідності перебудови існуючих фрорм, коли увага науковців концентрувалася на окремих локалізаціях злоякісних пухлин або на групі пухлин різного етіопатогенетичного походження. На сьогодні більш доцільним є системний, комплексний підхід до профрілактики та ранньої діагностики злоякісних пухлин [8-10].

Мета дослідження: встановити провідні фрактори у розвитку раку тіла матки і раку яєчників та на їх основі визначити основні групи ризику розвитку онкогінекологічної патології.

Матеріали і методи. За допомогою проведеного епідеміологічного дослідження з використанням карти дослідження онкогінекологічного хворого встановлено порівняльні відмінності групи здорових жінок та таких, які захворіли на рак тіла матки або яєчників. На основі отриманих результатів сорормовано фрактори ризику виникнення онкогінекологічної патології у жінок. Епідеміологічне дослідження включало 278 жінок 
Тернопільської області за період 2014-2016 рр., серед яких у 155 діагностовано рак тіла матки та у 123 - рак яєчників. Для порівняльної оцінки контрольну групу склали 47 здорових жінок віком від 25 до 70 років.

Отримані цифрові величини обробляли 3 використанням методів варіаційної статистики. Для оцінки взаємозв'язку визначали $\chi^{2}$ Пірсона.

Результати дослідження та їх обговорення. Важливим фрактором, що впливає на розвиток онкогінекологічної патології, є віковий фрактор. Так, відповідно до проведених епідеміологічних досліджень встановлено, що найвищий рівень захворюваності на злоякісні новоутворення тіла матки належить до вікових груп від 55 до 75 років. Найвищий рівень захворюваності на рак яєчників припадає на віковий період 65-69 років.

Генетичні фрактори відіграють не менш важливу роль у розвитку онкогінекологічної патології. Проведеним анкетуванням встановлено, що серед осіб, які захворіли на рак тіла матки, у 3,9 \% випадків матері мали онкопатологію, а у 1,9 \% - хворів батько. Серед осіб з раком яєчників онкопатологію у матері було діагностовано в 3,3 \% випадків. Окрім цього, онкологічні захворювання встановлено у 3,8 \% дідусів і в 2,7 \% - бабусів.

Також необхідно вказати і те, що у жінок, родичі яких хворіли на рак тіла матки або рак яєчників, пухлини спостерігали в 1,4 раза частіше.

Особливо важливе значення необхідно приділяти при вивченні раку тіла матки та яєчників розладам менструального циклу. Частота розладів менструального циклу у хворих на рак тіла матки виразно зростає у клімактеричному періоді. Згідно з отриманими результатами епідеміологічного дослідження встановлено, що менопауза у хворих на рак матки в середньому настає у віці 49-60 років, на противагу тому, як у практично здорових людей у віці 48-50 років.

Аналізуючи роль особливостей менструального циклу у розвитку злоякісних пухлин тіла матки та яєчників, ми зробили детальний акцент щодо вивчення віку, в якому розпочалися перші місячні, часу, протягом якого встановився регулярний менструальний цикл, тривалості менструального циклу, віку початку менопаузи, особливостей менструального циклу.

Доведено, що розлади менструального циклу взаємопов'язані з розвитком раку тіла матки та раку яєчників.

Результати епідеміологічних досліджень щодо віку, в якому розпочалися перші місячні у жінок досліджуваних груп та контрольної групи (здорових жінок), наведено у таблиці 1.

За даними таблиці 1, у контрольній групі, що включала здорових жінок, місячні в основному розпочиналися у віці від 11 до 14 років. У жінок, які захворіли на рак тіла матки, частота початку місячних у даному віці зменшувалася в 1,3 раза, а у жінок, які захворіли на рак яєчників, у 1,07 раза. Рівень значущості поширеності ознак був достовірним для даних груп спостереження $(p<0,05)$. Початок перших місячних у віці 15 років і більше статистично достовірно частіше спостерігали у хворих із гормонозалежними пухлинами та раком тіла матки $(p<0,05)$.

\section{Таблиця 1. Вік, у якому розпочалися перші місячні у хворих на рак тіла матки, яєчників}

\begin{tabular}{|c|c|c|c|c|c|c|c|}
\hline \multirow{3}{*}{ Досліджувана група } & \multicolumn{6}{|c|}{ Вік початку місячних, роки } & \multirow{3}{*}{$\begin{array}{c}\text { Рівень } \\
\text { значущості } \chi^{2} \\
\text { критерію }\end{array}$} \\
\hline & \multicolumn{2}{|c|}{ до 10} & \multicolumn{2}{|c|}{$11-14$} & \multicolumn{2}{|c|}{15 і більше } & \\
\hline & абс. & $\%$ & абс. & $\%$ & абс. & $\%$ & \\
\hline Рак тіла матки, n=155 & - & - & 88 & 56,8 & 67 & 43,2 & $p<0,05$ \\
\hline Рак яєчників, $\mathrm{n}=123$ & - & - & 86 & 69,9 & 37 & 30,1 & $p<0,05$ \\
\hline $\begin{array}{l}\text { Контрольна група } \\
\text { (здорові жінки), n=47 }\end{array}$ & 1 & 2,1 & 35 & 74,5 & 11 & 23,4 & \\
\hline
\end{tabular}

Анамнестичними опитуваннями жінок доведено, що характер встановлення місячних не має взаємозв'язку з розвитком раку тіла матки та яєчників. Як у здорових жінок, так і у $94 \%$ хворих місячні встановилися протягом перших трьох місяців. При аналізі результатів анкетування щодо тривалості менструального циклу в хворих на рак жіночих статевих органів та у здорових жінок визначено, що питома частка короткого менструального циклу (тривалістю 21-23 дні) у жінок із діагностованим раком тіла матки в 1,49 раза переважала таку у здорових жінок. Окрім цього, відносні показники кількості жінок, у яких тривалість менструального циклу становила від 28 до 30 днів, були більшими від контрольної групи у 1,29 раза. Також доведено, що суттєвої різниці у хворих на рак яєчників та контрольною групою здорових жінок не визначалося.

Дані про тривалість менструації у хворих та здорових жінок наведено в таблиці 2. За результатами анкетування встановлено, що у більшості здорових жінок менструальні виділення тривають від 3 до 5 днів (78,7 \%) і, практично, для досліджуваних осіб це потрібно вважати нормою. Проте у хворих на рак яєчників у 3,47 раза більше було випадків зі зменшеною тривалістю менструації до 
1-2 днів, а при раку тіла матки, навпаки, збільшувалася в 1,18 раза питома частка осіб, в яких тривалість менструації була 6 і більше днів. Як показала статистична перевірка $\left(\chi^{2}\right)$, тривалі, а особливо, короткотривалі місячні, мають визначені зв'язки в цілому для виникнення злоякісних пухлин тіла матки та яєчників.

Аналізуючи результати анкетних даних ми визначили особливості менструального циклу в жінок, які захворіли на рак яєчників та рак тіла матки. У жінок із раком тіла матки у 22,3\% випадків спостерігали сильний головний біль, у 16,2 \% - загальну слабість, у 27,2 \% - набрякання молочних залоз, 14,5 \% - біль внизу живота, дратівливість у $18,3 \%$.

Для жінок, які захворіли на рак яєчників, характерними скаргами були під час менструального циклу головний біль, який відзначали у 10,4 \% опитанихжінок, слабість-у 7,9\% випадків, набрякання молочних залоз - у 10,2 \%, біль внизу живота в 18,9 \% випадків, інші скарги - у 24,5 \%, безсимптомний перебіг місячного циклу - в 28,1\%.

Якщо в генезі злоякісних пухлин тіла матки та яєчників визначне значення мають пізній початок місячних, то ймовірність впливу на розвиток даної патології має також і вік початку менопаузи (табл. 3).

Таблиця 2. Тривалість менструації у хворих з онкогінекологічною патологією і здорових жінок контрольної групи

\begin{tabular}{|c|c|c|c|c|c|c|c|}
\hline \multirow{3}{*}{ Досліджувана група } & \multicolumn{6}{|c|}{ Тривалість менструації, доби } & \multirow{3}{*}{$\begin{array}{c}\text { Рівень } \\
\text { значущості } \chi^{2} \\
\text { критерію }\end{array}$} \\
\hline & \multicolumn{2}{|c|}{$1-2$} & \multicolumn{2}{|c|}{$3-5$} & \multicolumn{2}{|c|}{6 і більше } & \\
\hline & абс. & $\%$ & абс. & $\%$ & абс. & $\%$ & \\
\hline Рак тіла матки, n=155 & 3 & 1,9 & 117 & 75,5 & 35 & 22,6 & $p<0,05$ \\
\hline Рак яєчників, $n=123$ & 9 & 7,3 & 102 & 82,9 & 12 & 9,8 & $p<0,05$ \\
\hline $\begin{array}{l}\text { Контрольна група } \\
\text { (здорові жінки), n=47 }\end{array}$ & 1 & 2,1 & 37 & 78,7 & 9 & 19,1 & \\
\hline
\end{tabular}

Таблиця 3. Вік початку менопаузи у жінок з онкогінекологічною патологією

\begin{tabular}{|c|c|c|c|c|c|c|c|}
\hline \multirow{3}{*}{ Досліджувана група } & \multicolumn{6}{|c|}{ Початок менопаузи, роки } & \multirow{3}{*}{$\begin{array}{c}\text { Рівень } \\
\text { значущості } \chi^{2} \\
\text { критерію }\end{array}$} \\
\hline & \multicolumn{2}{|c|}{ до 45} & \multicolumn{2}{|c|}{$45-50$} & \multicolumn{2}{|c|}{51 і більше } & \\
\hline & абс. & $\%$ & абс. & $\%$ & абс. & $\%$ & \\
\hline Рак тіла матки, n=67 & 13 & 19,4 & 12 & 17,9 & 42 & 62,7 & $p<0,05$ \\
\hline Рак яєчників, n=63 & 15 & 23,8 & 13 & 20,6 & 35 & 55,6 & $p<0,05$ \\
\hline $\begin{array}{l}\text { Контрольна група } \\
\text { (здорові жінки), n=38 }\end{array}$ & 5 & 13,2 & 17 & 44,7 & 16 & 42,1 & \\
\hline
\end{tabular}

Стан гормонального балансу в організмі жінки в основному визначає вік початку клімактеричного періоду, періоду закінчення менструації. Багато в чому залежать від гормонального балансу передменопаузальний та постменопаузальний періоди. У зв'язку з цим, при вивченні епідеміології раку тіла матки та яєчників особливе місце займає оцінка ряду параметрів, які пов'язані з характеристикою гормональної фрунції жінки.

За даними анкетування, у жінок з раком тіла матки менопауза у віці до 45 років частіше розвивалася, порівняно зі здоровими жінками, в 1,46 раза, а у віці 51 рік і більше, в 1,49 раза $(p<0,05)$. Частота настання менопаузи у віці 45-50 років у 2,5 раза визначалася меншою, порівняно зі здоровими жінками $(p<0,05)$.

У хворих на рак яєчників розвиток менопаузи у віці до 45 років у 1,8 раза був частішим, ніж у здорових жінок $(p<0,05)$. Також необхідно відзначити, що розвиток менопаузи у віці після 50 років переважав у 1,32 раза контрольні дані ( $<<0,05)$.

При порівнянні частоти розвитку менопаузи у жінок, які хворіли на рак тіла матки та рак яєчників, встановлено, що розвиток менопаузи до 45 років при раку яєчників визначали у 1,23 раза частіше, а розвиток менопаузи був частішим у 1,13 раза у 51 рік і старших жінок при раку тіла матки.

Таким чином, фракторами ризику розвитку онкопатології матки та яєчників $є$ раннє настання менопаузи та розвиток менопаузи у віці 51 рік і більше. Причому більшою настороженістю при раку яєчників повинна бути рання менопауза у віці до 45 років, а пізня менопауза після 51 року стосується більш характерних фракторів ризику раку тіла матки.

Сімейний стан має безпосередній зв'язок зі здоров'ям жінки. Проведеними епідеміологічними дослідженнями встановлено, що незаміжні жінки в 1,22 раза частіше хворіли на рак тіла матки та в 1,65 раза - на рак яєчників. Серед жінок, які залишилися вдовами, кількість осіб, які захворіли на рак тіла матки, збільшувалася в 3,04 раза, а на рак яєчників - в 1,2 раза. Гінекологічне здоров'я розлучених жінок та жінок, які перебувають у шлюбі, значно відрізнялося. Так, серед розлучених жінок захворюваність на рак тіла матки збільшувалася в 1,5 раза, а на рак яєчників - у 1,62 раза. 
Отже, визначеними фракторами ризику виникнення злоякісних пухлин тіла матки та яєчників у жінок може бути відсутність статевого життя. Статистично достовірною $(p<0,05)$ визначена залежність виникнення раку тіла матки від родів.

Для встановлення залежності розвитку раку тіла матки та раку яєчників від сексуальної поведінки жінок проведеним епідеміологічним дослідженням виявлено, що цнотливі жінки в 1,21 раза частіше хворіли на рак тіла матки та в 1,65 раза - на рак яєчників. Результати анкетування показують, що серед досліджуваної популяції жінок, які захворіли на рак тіла матки, 7,2 \% розпочали статеве життя у віці до 17 років, 62,7 \% - у віці від 17 до 22 років, $18,4 \%$ - у віці від 23 до 27 років та 8,1 \% - у віці 28 років і більше. Серед опитаних жінок 3,6 \% були цнотливими.

Серед жінок, які захворіли на рак яєчників, статеве життя у віці до 17 років розпочали 6,1 \%, у віці від 17 до 22 років - 53,6 \%, у віці від 23 до 27 років 26,3 \%, у віці 28 і більше - 11,3 \%. У даній групі жінок 4,7 \% були цнотливими.

Важливе значення у розвитку онкогінекологічної патології має вік припинення статевого життя жінками (табл. 4). За наведеними у таблиці результатами, опитування жінок з онкопатологією та здорових жінок різних вікових груп встановлено, що серед захворілих на рак тіла матки статеве життя у віці від 30 до 40 років припинили 10,3 \% опитаних, що у 2,19 раза перевищує отримані дані у контрольній групі здорових жінок. У віці від 40 до 45 років з питомої частки жінок, які захворіли на рак тіла матки, припинили статеве життя 10,3 \% жінок, і різниця даних параметрів із контрольною групою становить 45,1 \%. Дещо більшим визначався коефіцієнт відношення питомої частки жінок, які припинили статеве життя у віці від 45 до 49 років, переважав контрольні дані в 1,55 раза. У віці 50 років і більше мала місце дещо інша картина відношень питомої частки осіб, які припинили статеве життя. Навпаки, кількість жінок зменшувалася у групі тих, які захворіли на рак тіла матки, а даний показник у контрольній групі становив 71,5 \%, переважаючи на 33,6 \% питому частку осіб з раком тіла матки ( $\mathrm{p}<0,05)$.

Серед жінок, які захворіли на рак яєчників, статеве життя у віці від 40 до 45 років припинили
26,5 \%, що в 3,7 раза більше від контрольної групи здорових. У віці 45-49 років відношення показників даної групи і контролю складає 1,96 раза. Серед опитаної групи жінок, які захворіли на рак яєчників, питома частка тих, які припинили статеве життя у віці 50 років і більше, становила 36,0 \% і була меншою від контролю в 1,99 раза та меншою від аналогічних показників визначених у групі жінок, які захворіли на рак тіла матки на 48,6 \%.

Таким чином, встановлено, що припинення статевого життя $є$ одним із фракторів ризику розвитку раку тіла матки та раку яєчників. Припинення статевого життя у віці від 40 років у 3,7 раза збільшує ймовірність щодо захворювання на рак яєчників.

Важливою умовою для визначення епідеміологічної картини фракторів ризику розвитку онкогінекологічних захворювань $€$ встановлення даних щодо впливу віку жінки при першій вагітності на виникнення злоякісних пухлин репродуктивної системи. Серед досліджуваних груп визначено, що як у контрольній групі здорових жінок, так і у групі жінок, хворих на рак тіла матки та рак яєчників, визначали на одному рівні питому частку жінок, які народжували до 17 років, що становила від 0,5 до 1,0 \%. Існуюча різниця встановлена при порівнянні питомої частки жінок, які вперше народжували у віці від 30 до 35 років та захворіли на рак тіла матки або рак яєчників із контрольною групою. При цьому питома частка таких при раку тіла матки була більшою на 47,3 \%, а при раку яєчників - на 52,6 \%.

Великою проблемою демографрічних процесів, а також здоров'я жінок, є аборти. Перебудова гормональної системи при самовільних абортах $€$ меншою на відміну від штучного переривання вагітності. Особливо небезпечні часті аборти. Останнє позначається на морфофрункціональному стані яєчників, тілі матки та інших гормонозалежних органів.

Аборти є найбільш доведеним фрактором ризику виникнення злоякісних пухлин жіночих статевих органів як в цілому, так і відносно певного органа (табл. 5).

При цьому в жінок, які захворіли на рак яєчників, визначалася найбільша питома частка абортів, серед яких у 74,2 \% було штучне переривання вагітності і лише у 25,8 \% - самовільні аборти, що

Таблиця 4. Вік припинення статевого життя у хворих на рак та здорових жінок

\begin{tabular}{|c|c|c|c|c|c|c|c|c|c|}
\hline \multirow{3}{*}{ Досліджувана група } & \multicolumn{8}{|c|}{ Вік припинення статевого життя, роки } & \multirow{3}{*}{$\begin{array}{c}\text { Рівень } \\
\text { значущості } \chi^{2} \\
\text { критерію }\end{array}$} \\
\hline & \multicolumn{2}{|c|}{$30-40$} & \multicolumn{2}{|c|}{$40-45$} & \multicolumn{2}{|c|}{$45-49$} & \multicolumn{2}{|c|}{50 і більше } & \\
\hline & абс. & $\%$ & абс. & $\%$ & абс. & $\%$ & абс. & $\%$ & \\
\hline Рак тіла матки, $\mathrm{n}=58$ & 6 & 10,3 & 6 & 10,3 & 15 & 25,9 & 31 & 53,5 & $p<0,05$ \\
\hline Рак яєчників, $\mathrm{n}=64$ & 3 & 4,7 & 17 & 26,5 & 21 & 32,8 & 23 & 36,0 & $p<0,05$ \\
\hline $\begin{array}{c}\text { Контрольна група } \\
\text { (здорові жінки), n=42 }\end{array}$ & 2 & 4,7 & 3 & 7,1 & 7 & 16,7 & 30 & 71,5 & \\
\hline
\end{tabular}


Таблиця 5. Аборти у хворих на рак органів репродуктивної системи

\begin{tabular}{|c|c|c|c|c|c|c|c|c|c|c|}
\hline \multirow{3}{*}{ Локалізація } & \multirow{3}{*}{ Всього } & \multirow{2}{*}{\multicolumn{2}{|c|}{ Всі аборти }} & \multicolumn{6}{|c|}{ Самовільні аборти } & \multirow{3}{*}{$\begin{array}{c}\text { Рівень } \\
\text { значущості } \\
\chi^{2} \text { критерію }\end{array}$} \\
\hline & & & & \multicolumn{2}{|c|}{ всього } & \multicolumn{2}{|c|}{ з вишкрібанням } & \multicolumn{2}{|c|}{ без вишкрібання } & \\
\hline & & абс. & $\%$ & абс. & $\%$ & абс. & $\%$ & абс. & $\%$ & \\
\hline Рак тіла матки & 155 & 37 & 23,9 & 9 & 5,8 & 5 & 3,2 & 4 & 2,6 & $p<0,05$ \\
\hline Рак яєчників & 123 & 31 & 25,2 & 8 & 6,5 & 3 & 2,4 & 5 & 4,1 & $p<0,05$ \\
\hline $\begin{array}{l}\text { Контрольна група } \\
\text { (здорові жінки) }\end{array}$ & 47 & 7 & 14,9 & 1 & 2,1 & - & - & 1 & 2,1 & \\
\hline
\end{tabular}

супроводжувалися або не супроводжувалися вишкрібанням. Питома частка жінок, які захворіли на рак тіла матки та мали в анамнезі аборти, була дещо меншою. Проте серед абортів частка самовільних абортів становила 75,7 \%, що дещо більше порівняно $з$ аналогічним контингентом жінок, які захворіли на рак яєчників. У жінок, хворих на рак тіла матки, серед самовільних абортів було більше таких, що супроводжувалися вишкрібанням матки.
Застосування засобів і способів запобігання вагітності характеризувалися достовірними показниками оцінки статистичної значущості та взаємозв'язку у виникненні онкогінекологічної патології. Серед жінок, які захворіли на рак тіла матки, питома частка таких, які різними способами та методами запобігали вагітності, була меншою від контрольної групи здорових жінок в 1,5 раза, а у хворих на рак яєчників - у 1,7 раза (табл. 6).

Таблиця 6. Застосування засобів запобігання вагітності у хворих та здорових жінок

\begin{tabular}{|c|c|c|c|c|c|c|c|c|c|c|}
\hline \multirow{3}{*}{ Локалізація } & \multirow{3}{*}{ Всього } & \multirow{2}{*}{\multicolumn{2}{|c|}{$\begin{array}{c}\text { Запобігали } \\
\text { вагітності }\end{array}$}} & \multicolumn{6}{|c|}{ Засоби запобігання вагітності } & \multirow{3}{*}{$\begin{array}{c}\text { Рівень } \\
\text { значущості } \\
\chi^{2} \text { критерію }\end{array}$} \\
\hline & & & & \multicolumn{2}{|c|}{ медикаментозні } & \multicolumn{2}{|c|}{ механічні } & \multicolumn{2}{|c|}{ спіраль } & \\
\hline & & абс. & $\%$ & абс. & $\%$ & абс. & $\%$ & абс. & $\%$ & \\
\hline Рак тіла матки & 155 & 68 & 43,8 & 6 & 3,8 & 9 & 5,8 & 2 & 1,3 & $p<0,05$ \\
\hline Рак яєчників & 123 & 46 & 37,4 & 5 & 4,1 & 9 & 7,3 & 1 & 0,8 & $p<0,05$ \\
\hline $\begin{array}{l}\text { Контрольна група } \\
\text { (здорові жінки) }\end{array}$ & 47 & 31 & 65,9 & 2 & 4,3 & 6 & 12,8 & 3 & 6,4 & \\
\hline
\end{tabular}

При цьому у всіх групах жінок переважали механічні засоби запобігання вагітності. Також характерною особливістю $є$ і те, що у групі здорових жінок значно більшою була питома частка жінок, які користувалися способом застосування спіралі.

Питання про взаємозв'язки окремих шкідливих звичок із ризиком виникнення деяких видів злоякісних пухлин залишається актуальним і для жіночої статевої сфрери. Так, серед жінок 3 онкогінекологічною патологією куріння спостерігали у 3,4 раза частіше, ніж у контрольній групі, яку склали здорові жінки. Серед курящих переважали жінки, які курять 5 і більше років.

Як відомо, виникненню злоякісних пухлин майже завжди передують ті чи інші хвороби. Такі захворювання можуть мати загальний або локальний характер, вони можуть бути як фоновими, так i супутніми. Серед хвороб, які можуть впливати на виникнення раку тіла матки та яєчників, у наших дослідженнях частіше всього спостерігали ендокринно-обмінні порушення, які супроводжувалися ожирінням, цукровим діабетом та підвищенням артеріального тиску. Серед досліджуваних груп у жінок, які захворіли на рак тіла матки, 61,3\% мали ендокринно-обмінні порушення, а у групі хворих на рак яєчників - 52,1 \%. У групі здорових жінок ендокринно-обмінні порушення склали лише 23,1 \%. Статистично встановлено достовірну залежність розвитку злоякісних пухлин від ендокринно-обмінних порушень $(p<0,05)$ (табл. 7). Надмірна маса тіла, яка $є$ найхарактернішою для раку тіла матки, поєднувалася часто з підвищенням артеріального тиску.

Таблиця 7. Ендокринно-обмінні захворювання у жінок з онкогінекологічною патологією та здорових жінок

\begin{tabular}{|c|c|c|c|c|c|c|c|c|c|c|}
\hline \multirow{3}{*}{ Локалізація } & \multirow{3}{*}{ Всього } & \multirow{2}{*}{\multicolumn{2}{|c|}{$\begin{array}{c}\text { Ендокринно- } \\
\text { обмінні хвороби }\end{array}$}} & \multicolumn{6}{|c|}{ Хвороби } & \multirow{3}{*}{$\begin{array}{c}\text { Рівень } \\
\text { значущості } \chi^{2} \\
\text { критерію }\end{array}$} \\
\hline & & & & \multicolumn{2}{|c|}{ ожиріння } & \multicolumn{2}{|c|}{ гіпертензія } & \multicolumn{2}{|c|}{ цукровий діабет } & \\
\hline & & абс. & $\%$ & абс. & $\%$ & абс. & $\%$ & абс. & $\%$ & \\
\hline Рак тіла матки & 155 & 95 & 61,3 & 56 & 36,1 & 28 & 18,1 & 11 & 7,1 & $p<0,05$ \\
\hline Рак яєчників & 123 & 64 & 52,1 & 39 & 31,7 & 19 & 15,4 & 6 & 4,9 & $p<0,05$ \\
\hline $\begin{array}{l}\text { Контрольна } \\
\text { група (здорові } \\
\text { жінки) }\end{array}$ & 47 & 10 & 21,3 & 6 & 12,8 & 3 & 6,4 & 1 & 2,1 & \\
\hline
\end{tabular}


Так, у жінок, хворих на рак тіла матки, питома частка тих, які мали надмірну масу тіла у 2,8 раза переважала контрольні дані $(p<0,05)$, а частка осіб із гіпертензією у 2,7 раза. Серед хворих на рак тіла матки, порівняно зі здоровими жінками, відносні величини хворих із цукровим діабетом були більшими в 3,4 раза.

Серед жінок, які були хворі на рак яєчників, питома частка осіб із надмірною масою тіла була більшою від контрольних величин у 2,5 раза, а осіб 3 підвищеним артеріальним тиском - у 2,4 раза. Також встановлено, що серед хворих на рак яєчників у 2,4 раза переважали контрольні дані особи із супутнім цукровим діабетом. Важливо відзначити, що у контрольній групі, до якої ввійшли здорові жінки, кількість осіб, які мали надмірну масу тіла, становила лише 12,8 \%. Таким чином, можна вважати, що до фракторів ризику захворювання на рак тіла матки та рак яєчників можна віднести надмірну масу тіла, а також гіпертензію та цукровий діабет.

Ми проаналізували також роль у виникненні злоякісних пухлин тіла матки та яєчників таких захворювань, як ерозія шийки матки, хронічні запальні захворювання матки та яєчників, фріброміома матки, поліпоз матки (табл. 8).

Таблиця 8. Гінекологічні захворювання у хворих із онкогінекологічною патологією та у здорових жінок

\begin{tabular}{|c|c|c|c|c|c|c|c|c|c|c|}
\hline \multirow[t]{2}{*}{ Локалізація } & \multicolumn{2}{|c|}{$\begin{array}{c}\text { Ерозія шийки } \\
\text { матки }\end{array}$} & \multicolumn{2}{|c|}{$\begin{array}{c}\text { Запальні } \\
\text { захворювання } \\
\text { матки і яєчників }\end{array}$} & \multicolumn{2}{|c|}{$\begin{array}{c}\text { Фіброміома } \\
\text { матки }\end{array}$} & \multicolumn{2}{|c|}{ Поліпоз матки } & \multicolumn{2}{|c|}{$\begin{array}{c}\text { Інші гінекологічні } \\
\text { хвороби }\end{array}$} \\
\hline & абс. & $\%$ & абс. & $\%$ & абс. & $\%$ & абс. & $\%$ & абс. & $\%$ \\
\hline Рак тіла матки & 10 & 6,4 & 15 & 9,7 & 9 & 5,8 & 8 & 5,2 & 33 & 21,3 \\
\hline Рак яєчників & 7 & 5,7 & 13 & 10,6 & 5 & 4,1 & 4 & 3,3 & 21 & 17,1 \\
\hline $\begin{array}{l}\text { Контрольна група } \\
\text { (здорові жінки) }\end{array}$ & 2 & 4,2 & 2 & 4,2 & 1 & 2,1 & - & - & 5 & 10,6 \\
\hline
\end{tabular}

Проведеним епідеміологічним дослідженням встановлено, що ерозія шийки матки в 1,53 раза $(p<0,05)$, порівняно зі здоровими жінками, які входили до контрольної групи, частіше спостерігалася у хворих на рак тіла матки та в 1,38 раза - у хворих на рак яєчників. Запальні гінекологічні захворювання у жінок з раком тіла матки, порівняно зі здоровими жінками, частіше спостерігали у 2,3 раза $(p<0,001)$, а у випадку раку яєчників - у 2,5 раза $(p<0,001)$. Серед предикторів онкогінекологічної патології важливу роль відіграють фріброміоматозні зміни матки та поліпозні розростання внутрішньої оболонки. За результатами порівняння наведених у таблиці досліджуваних даних, можна стверджувати, що поліпозні розростання внутрішньої оболонки матки безпосередньо пов'язані з розвитком онкогінекологічної патології як тіла матки, так і яєчників, а частота виникнення фріброміоми у 2,7 раза $€$ більшою у жінок, хворих на рак тіла матки та в 1,9 раза - на рак яєчників.

Інші гінекологічні хвороби ми об'єднали в окрему досліджувану групу. При цьому встановлено, що відносні величини даної групи у хворих на рак тіла матки у 2 рази переважали контрольні параметри
( $p<0,05)$, а у групі жінок з раком яєчників у 1,6 раза, таким чином засвідчуючи їхнє відношення до фракторів ризику виникнення онкологічної патології.

Отже, серед системних та локальних хвороб важливе місце в розвитку онкогінекологічної патології поряд з іншими фракторами ризику займають ендокринно-обмінні та локальні фонові захворювання.

За результатами отриманих даних епідеміологічних досліджень ми проаналізували контингент хворих на рак тіла матки та рак яєчників, а також здорових жінок та виділили групи за кількістю фракторів ризику (табл. 9).

За кількістю фракторів ризику можна встановити прогностичні критерії щодо можливостей виникнення онкогінекологічної патології. Згідно з даними таблиці 9, один фрактор ризику визначався у 74,5 \% здорових осіб, а серед групи хворих з онкогінекологічною патологією у 100 \%. Два, а також три фрактори ризику також мали місце у 100 \% хворих жінок. Чотири фрактори ризику в групі хворих встановлено у 97,5 \%, а у здорових жінок - у 10,6 \% осіб.

Критерієм для включення жінок у групу ризику ми визначили наявність чотирьох і більше фракторів ризику. Отже, з даними групами ризику, що

Таблиця 9. Частота факторів ризику виникнення онкогінекологічної патології

\begin{tabular}{|l|c|c|c|c|c|c|c|}
\hline \multirow{2}{*}{ Контингент } & \multirow{2}{*}{ Всього } & \multicolumn{5}{|c|}{ Наявність факторів ризику } \\
\cline { 3 - 8 } & & одного & двох & трьох & чотирьох & \multicolumn{1}{c|}{ п'яти } & шести \\
\hline Хворі & 278 & 278 & 278 & 278 & 271 & 264 & 256 \\
& & $100 \%$ & $100 \%$ & $100 \%$ & $97,5 \%$ & $94,9 \%$ & $92,1 \%$ \\
\hline Здорові & 47 & 35 & 24 & 11 & 5 & 3 & 1 \\
(контрольна група & & $74,5 \%$ & $51,1 \%$ & $23,4 \%$ & $10,6 \%$ & $6,3 \%$ & $2,1 \%$ \\
\hline
\end{tabular}


мають чотири і більше фракторів, потрібно проводити відповідну роботу щодо попередження розвитку онкогінекологічної патології. Для цього на базовому, а також галузевому рівнях повинні бути розроблені профрілактичні програми.

Підсумовуючи результати отриманих досліджень можна виділити фрактори, які, за нашими даними, мають місце при раку тіла матки, а також при раку яєчників. Найбільш інфрормативними є вік, відсутність шлюбу, пізня та рання менопаузи, нерегулярне або перерване статеве життя, штучні аборти, ендокринно-обмінні захворювання. У результаті порівняння фракторів ризику ми створили синоптичну таблицю, в яку включили фактори, які найчастіше спостерігали у хворих на рак тіла матки та рак яєчників (табл. 10).

Таблиця 10. Синоптична таблиця фракторів ризику онкогінекологічної патології

\begin{tabular}{|l|}
\hline \multicolumn{1}{|c|}{ Фактори ризику } \\
\hline Вік від 50 до 75 років \\
\hline Початок місячних у віці 15 років і більше \\
\hline Тривалість місячних менше 2 або більше 6 діб \\
\hline Цнотливість \\
\hline Одинокість \\
\hline Відсутність родів \\
\hline Штучні аборти \\
\hline Менопауза до 45 або більше 50 років \\
\hline Ендокринно-обмінні захворювання \\
\hline Фонові гінекологічні захворювання \\
\hline
\end{tabular}

Наведені дані потрібно враховувати при срормуванні комплексних програм профрілактики і ранньої діагностики онкогінекологічної патології, зокрема раку тіла матки та раку яєчників.

Контингент населення, який включено до групи ризику на момент обстеження, може бути практично здоровим, проте наявність фракторів ризику, а особливо віднесення до групи ризику, вимагає систематичного диспансерного спостереження та поглибленого обстеження.

При цьому для включення жінок до групи ризику необхідно запровадити при першій зустрічі 3 ciмейним лікарем анкетування жінок із подальшим визначенням їхньої групи ризику.

\section{Висновки}

1. Відповідно до запропонованої нами синоптичної таблиці доцільним є виділення таких трьох груп ризику у жінок: перша група - хворі на рак, передракові та фонові захворювання тіла матки і яєчників; друга група - практично здорові жінки 3 чотирма і більше фракторами ризику; третя група практично здорові жінки з 1-3 фракторами ризику, які мають незначну питома частку у виникненні онкогінекологічної патології.

2. Подальша тактика з контингентом встановлених груп повинна полягати в наступному:

- жінки, які належать до першої групи, повинні бути направлені у спеціалізовані онкологічні заклади для лікування;

- особи, які ввійшли до другої групи, підлягають диспансерному спостереженню та поглибленому профрілактичному обстеженню із застосуванням цитології, кольпоскопії, ехограсрії та інших високоінформативних діагностичних способів обстеження;

- для контингенту осіб, які включені до третьої групи, доцільним $€$ застосування періодичного профрілактичного обстеження.

Перспективи подальших досліджень полягають в удосконаленні системи раннього виявлення та профрілактики онкогінекологічної патології.

\section{Список літератури}

1. Акушерсько-гінекологічна допомога у закладах охорони здоров'я, що перебувають у сфері управління МОЗ України : аналітично-статистичний довідник за 2008 р. - К., 2009. - 176 с.

2. Инфекции, преимущественно передаваемые половым путем : материалы круглого стола // Здравоохранение. 2012. - № 1. - С. 25-27.

3. Онкологическая статистика [Электронный документ]. - Режим доступа : http://apps.who.int/rhl/effective_practice_ and_organizing_care/rpcom2/ru. - Название с экрана.

4. Рак в Україні 2015-2016 : бюлетень Національного канцер-реєстру України. - К., 2006. - № 18. - 112 с.

5. Рак в Україні. 2008-2009 роки. Захворюваність, смертність, показники діяльності онкологічної служби : бюлетень Національного канцер-реєстру України / Національний інститут раку. - К., 2010. - № 11. - 107 с.

6. Статистичні дані 2014-2016 рр. [Електронний ресурс] / Центр медичної статистики МОЗ України. - Режим доступу : http://medstat.gov.ua. - Назва з екрана. 
7. Epidemiological guidelines for quality assurance in cervical cancer screening / A. Anttila, G. Ronco, E. Lynge [et al.] // In: European guidelines for quality assuranceon cervical cancer screening / M. Arbyn, A. Anttila, J. Jordan [et al.] (Eds.). - 2nd ed. - Brussels : European Community, - 2008. - 324 p.

8. International Agency for Research on Cancer Cervix Cancer Screening // Handbooks of Cancer Prevention. - Lyon : IARC Press, 2005. - Vol. 10. - 302 p.

9. Epidemiologia nowotworów złośliwych w Polsce / Podstawy oncologii klinicznej. - Warszawa, 2011. - 263 s.

10. Worldwide burden of cervical cancer in 2008 / M. Arbyn, X. Castellsague, S. de Sanjose [et al.] // Annals of Oncology. 2011. - No. 22. - P. 2675-2686.

\section{References}

1. (2009). Akushersko-hinekolohichna dopomoha u zakladakh okhorony zdorovia, shcho perebuvaiut u sferi upravlinnia MOZ Ukrainy: analitychno-staystychnyi dovidnyk za $2008 \mathrm{r}$. [Obstetric and gynecological care in health care institutions in the management of the Ministry of Health of Ukraine: analytical and statistical guide for 2008]. Kyiv [in Ukrainian].

2. (2012). Infektsii, preimushchestvenno peredavayemye polovym putem: materially kruglogo stola [Sexually transmitted infections: round table materials]. Zdravookhranenie - Public Health, (1), 25-27 [in Russian].

3. Onkologicheskaya statistika [Oncological statistics]. [Electronic paper]. - Retrieved from: http://apps.who.int/rhl/ effective_practice_and_organizing_care/rpcom2/ru. - Title from the screen [in Russian].

4. (2006). Rak v Ukraini 2015-2016: biuleten Natsionalnoho kantser-reiestru Ukrainy [Cancer in Ukraine 2015-2015: Bulletin of the National Chancellery of Ukraine]. Kyiv [in Ukrainian].

5. (2010). Rak v Ukraini 2008-2009 roky. Zakhvoriuvanist, smertnist, pokaznyky diialnosti onkolohichnoi sluzhby: biuleten Natsionalnoho kantser-reiestru Ukrainy [Cancer in Ukraine 2008-2009. Incidence, mortality, indicators of the oncological service activity: Bulletin of the National Chancellery of Ukraine]. National Institute of Cancer. Kyiv [in Ukrainian].

6. Statystychni dani 2014-2016 [Statistical data 2014-2016] [Electronic resource]. Center of Medical Statistics of the Ministry of Health of Ukraine. - Retrieved from: http://medstat.gov.ua. - Title from the screen [in Ukrainian].

7. Anttila, A., Ronco, G., \& Lynge, E. (Eds.). (2008). Epidemiological guidelines for quality assurance in cervical cancer screening. In: European guidelines for quality assuranceon cervical cancer screening. - 2nd ed. - Brussels: European Community.

8. (2005). International agency for research on cancer cervix cancer screening. Handbooks of Cancer Prevention. Lyon: IARC Press.

9. Didkowska, J. (2001). Epidemiologia nowotworów złośliwych w Polsce. Podstawy Oncologii Klinicznej. Warszawa.

10. Arbyn, M., Castellsague, X., \& de Sanjose, S. (2011). Worldwide burden of cervical cancer in 2008. Annals of Oncology, 22, 2675-2686.

\section{СИНОПТИЧЕСКАЯ ХАРАКТЕРИСТИКА ФАКТОРОВ РИСКА ВОЗНИКНОВЕНИЯ РАКА ТЕЛА МАТКИ И РАКА ЯИЧНИКОВ}

М.П. Романив, В.Н. Михальчук

Национальная медицинская академия последипломного образования имени П. Л. Шупика, г. Киев, Украина

Цель: установить ведущие факторы в развитии рака тела матки и рака яичников и на их основе определить основные группы риска развития онкогинекологической патологии.

Материалы и методы. На основе проведенного эпидемиологического исследования, которое включало 278 женщин Тернопольской области за период 2014-2016 гг., среди которых у 155 диагностирован рак тела матки и в 123 - рак яичников, установлены факторы риска развития онкогинекологической патологии.

Результаты. Установлены фракторы риска, среди которых наиболее информативными являются возраст, отсутствие брака, поздняя и ранняя менопаузы, нерегулярная или прерванная половая жизнь, искусственные аборты, эндокринно-обменные заболевания.

Выводы. Выделены 3 группы риска развития у женщин онкогинекологической патологии: первая группабольные раковыми, предраковыми и фроновыми заболеваниями тела матки и яичников; вторая группа практически здоровые женщины из четырьма и более фракторами риска; третья группа - практически здоровые женщины с 1-3 факторами риска, имеющих незначительную удельную долю в возникновении онкогинекологической патологии.

КЛЮЧЕВЫЕ СЛОВА: рак тела матки; рак яичников; факторы риска.

\section{SYNOPTIC CHARACTERISTICS OF RISK FACTORS OF UTERINE AND OVARIAN CANCER}

M.P. Romaniv, V.M. Michalchuk

P. Shupyk National Medical Academy of Postgraduate Education, Kyiv, Ukraine

Purpose: to identify the leading factors in the development of ovarian and uterine cancer and determine the main risk groups for oncogynecological pathology.

Materials and Methods. On the basis of the conducted epidemiological research, which included 278 women from Ternopil region for the period of 2014-2016, among whom 155 were diagnosed with uterine cancer and $123-$ with ovarian cancer, the risk factors for oncogynecological pathology were determined. 
Results. Among the identified risk factors the most informative are: age, absence of marriage, late and early menopause, irregular or interrupted sex life, artificial abortions, endocrine-metabolic diseases.

Conclusions. There are 3 risk groups in women for oncogynecological pathology development:

- Group I - patients with precancerous and background diseases of the body of the uterus and ovaries;

- Group II - practically healthy women with 4 or more risk factors;

- Group III - practically healthy women with 1-3 risk factors a small proportion in the oncogynecological pathology.

KEY WORDS: uterine cancer; ovarian cancer, risk factors.

Рукопис надійшов до редакції 21.09.2017 p.

\section{Відомості про авторів:}

Романів Марія Павлівна - аспірант кафедри управління охороною здоров'я Національної медичної академії післядипломної освіти імені П.Л. Шупика.

Михальчук Василь Миколайович - завідувач кафедри управління охороною здоров'я Національної медичної академії післядипломної освіти імені П.Л. Шупика. 